\title{
USE OF ICT SERVICES AT FOOD PROCESSING ENTERPRISES AND THE INFORMATION SOCIETY DEVELOPMENT
}

\author{
Robert Nowacki, $\mathrm{PhD}^{1}$ \\ Faculty of Management and Finance, University of Economics and Human Sciences
}

\begin{abstract}
The aim of the article is to analyse the scale of use and to assess the services related to modern information and communication technologies at food processing enterprises and to identify the dependencies between the obtained indices and the features characterising the entities surveyed. The grounds for considerations are findings of the surveys with 201 managers of enterprises of this sector, differentiated in terms of size. The analysis comprised the three areas of ICT services: telecommunications services, services related to software and consultancy in the IT area, and information-related services. The results indicate a wide scope of the use of ICT services - telecommunication services are used by all the entities surveyed, those related to software and consultancy - by three quarters, while information-related services - by almost $60 \%$. In case of all entities there are noted growing outlays on their application, justified, on the one side, by the demand, and, on the other side, by high appraisals of their quality and up-to-datedness (more than $70 \%$ of indications) as well as their impact on competitiveness of the entities using them (percentages at the level of more than $60 \%$ ). It must be said that there occur quite big differences in the indices obtained, due to the features of the enterprises in question. Most often statistically significant dependencies appear in case of information-related services - they are determined by the size of enterprises and the origin of their capital. In case of the services related to software and IT consultancy, the said dependencies also concern the enterprises' size and, additionally, the range of their activities. Definitely most seldom the statistically significant dependencies occur in case of telecommunication services.
\end{abstract}

Keywords: food processing, ICT, ICT services, information society

JEL codes: D22, D83, L66, L86

\section{INTRODUCTION}

The contemporary economies to an ever growing degree depend on the development of information and communication technologies. They significantly affect the socioeconomic development, shape the social and economic trends, and the results achieved by this sector are significant for an overall economic performance (OECD, 2004). The notion of informa- tion and communication technologies, also called information and telecommunication technologies, ICT, telematics, relates in general to the family of technologies processing, collecting, and transmitting information in the electronic form (GUS, 2010). Such an approach goes far beyond the common understanding of this notion when it is related to computer science technologies, connected with the area of computerisation and implementation of IT solutions, while it

${ }^{1}$ Corresponding author: Pawia 55, 01-030 Warsaw, Poland, nowacki@vizja.pl, +48 601701213 
omits the issues of communication technologies, or connected with networks.

In the context of this study, there is adopted the definition and classification of the ICT sector based on the Statistical Classification of Economic Activities in the European Community (fr. Nomenclature statistique des Activités économiques dans la Communauté Européenne), NACE Rev. 2, according to which it covers the enterprises dealing with production, where the goods manufactured thereby allow for electronic processing of information and communication (including transmission and display), as well as the enterprises dealing with services, where the services provided allow for electronic processing of information and communication (GUS, 2010).

The aim of the article is to analyse the scale of use and to assess the services related to modern information and communication technologies at food processing enterprises and to identify the dependencies between the obtained indices and the features characterising the entities surveyed.

\section{THEORETICAL BACKGROUND}

The economic development is connected with continuous changes taking place in various areas of the contemporary world. One of the key processes is evolution towards the development of the information society. This term appeared in 1963, in the context of polemics of T. Umesao on the post-industrial society, initiated in 1959 by Bell (1973) and continued, i.a. by Machlup (1962), Drucker (1968, 1993), Castells (1996, 1997, 1998) as well as Toffler (1980) and his concept of the 'third wave', based on information and information and communication technology (ICT). At present, the information society is treated as a further stage after the industrial society (Nowacki, 2017).

The concept of information society had been primarily developing in Japan, then in the United States (Kluszczyński, 2001). The origin of formation of the information society in Europe goes to the year 1994, when the European Commission published the document entitled Europe and the Global Information Society: Recommendations to the European Council, whose author was Bangemann
(Dąbrowska, Janoś-Kresło and Wódkowski, 2009). Compliant to the document, the information society is defined as 'the society to which specific is preparedness and ability to use IT systems and to make use of telecommunication services for the purposes of information transmission and distant processing' (GUS, 2010). In Poland, for the purposes of Strategia rozwoju spoleczeństwa informacyjnego do roku 2013 [The Strategy of Development of Information Society up to the year 2013] (MSWiA, 2008), it is defined as such where 'information processing with the use of information and communication technologies is a considerable social, economic and cultural value'. In turn, according to Goban-Klas and Sienkiewicz (1999), this is 'the society which not only has developed means of information processing and communicating, but information processing is the basis for creation of national income and provides the sources of income of the majority of the society'. A similar definition is proposed by Kisielnicki (2008): 'this is such a society which has an access and can make use of IT infrastructure, information resources and knowledge for accomplishment of collective and individual aims in an efficient and economical way'. The two latter definitions emphasise the economic function fulfilled by the information society. In turn, Olszewski (2013) pays attention to the technological aspect, describing the information society as a "new type (...), who has formed up in the countries where the development of modern information technologies has reached a very fast rate'.

The level of development of the information society is decided by the three groups of indicators: those related to the sectors of ICT production and services, those connected with the use of ICT at enterprises, and those related to the use of ICT in households. From the point of view of this study, of the key importance are the two first groups of indicators. According to the CSO's data, in 2016, in Poland, there operated 2278 entities dealing with ICT production and services, which employed in aggregate 227,356 individuals and gained revenues at the level of $5.1 \%$ of total revenues of the sector of manufacturing and service businesses. Looking through the prism of the use of ICT at enterprises, the data for the year 2017 
show that $95.6 \%$ of them are equipped with computers, $94.8 \%$ have an access to the Internet, of which $95.1 \%$ - the broad-band access. $45.6 \%$ of employees use computers and $39.7 \%$ - computers with the access to the Internet (GUS, 2017).

\section{MATERIALS AND METHODS}

The grounds for considerations in this article are findings of the research carried out on a national sample of 201 enterprises operating in the sphere of food processing. The sampling was performed by the method of stratified quota sampling taking into consideration the three basic stratification criteria: the sector of activity, the size measured with the number of employees, and the headquarters location (Kuczewska and Nowacki, 2016). To describe the population surveyed there were used the three variables connected with the size, scope of activity, and capital origin (Table 1).

The research was carried out by the method of face-to-face interviews with managers of enterprises, based on an author's questionnaire with the questions related to various aspects of functioning in the market, including the use of services connected with ICT. The analysis covered the three categories of such services: telecommunication services, the services connected with software (increasing, creating, delivering, and documenting the software produced to the order, writing commissioned programmes, designing websites) and consultancy in the IT area (planning and designing the computer systems that combine hardware, software and communication technologies, including training for users) as well as services in the information area (covering data processing, website management, operation of Internet portals, and operation of information agencies).

The analysis of findings was carried out with the use of the statistical package IBM SPSS Statistics 24.0 , with the use of descriptive statistics and correlation coefficients between variables (nonparametric Mann-Whitney U test in case of independent variables, comprising two independent groups, and the Kruskal-Wallis test in case of independent variables comprising more than two independent groups) and their power (Cramer's V test in case of ascertainment of the statistically significant correlation). The analysis covered the use of ICT services and their multiaspect evaluation together with correlations between these issues and the three features describing the enterprises in question: the volume measured by the number of employees, the scope of activity, and capital origin.

Table 1. Structure of the sample of enterprises related to food processing

\begin{tabular}{|c|c|c|c|}
\hline \multicolumn{2}{|c|}{ Features of the surveyed enterprises } & $N$ & $\%$ \\
\hline$\times$ & Total & 201 & 100.0 \\
\hline \multirow{3}{*}{ Enterprise size } & from 10 to 49 employees & 32 & 15.9 \\
\cline { 2 - 4 } & from 50 to 249 employees & 75 & 37,3 \\
\cline { 2 - 4 } & 250 and more employees & 94 & 46.8 \\
\hline \multirow{3}{*}{ Range of operations } & local & 14 & 7.0 \\
\cline { 2 - 4 } & regional & 29 & 42.3 \\
\cline { 2 - 4 } & national & 85 & 36.3 \\
\cline { 2 - 4 } & international & 149 & 74.1 \\
\hline \multirow{3}{*}{ Capital structure } & Polish & 52 & 25.9 \\
\cline { 2 - 4 } & foreign / mixed & 73 & 43 \\
\hline
\end{tabular}

Source: author's own research, 2014/2015. 


\section{RESULTS AND DISCUSSION}

The carried out research shows that the use of ICT services is common. Telecommunication services are used by every market entity. Lower indices of the use are specific to the services related to software and IT consultancy $(74.6 \%)$ and the services related to information (59.2\%) - Table 2 . The characteristic phenomenon is the growing scale of the use of ICT services, measured with outlay dynamics. To the highest degree it concerns services related to information and services related to software and IT consultancy. Over the two years preceding the research there was noted the growth of spending on these services at 47.0 and $45.3 \%$, respectively, of the enterprises surveyed (with less than $5 \%$ of those indicating reduction in spending). The lower dynamics is specific to telecommunication services - the growth of outlays was declared by merely $31.9 \%$ of entities, while the drop - by $12.0 \%$.

ICT services are positively evaluated from the point of view of quality. More than $80 \%$ of the surveyed indicate high and very high quality of services related to software and consultancy as well as to information. And relatively often there is indicated the statement that their value is higher than the costs incurred for this account (almost 20\% of indications). Again, the worst is the case of telecommunication services for which the ratio showing their high quality drops to a little bit above $70 \%$, with the only $12.0 \%$ ratio indicating the favourable price and quality ratio. One can also see high assessment of innovativeness and up-to-datedness of ICT services. More than three quarters of the enterprises surveyed assign them such a score, while more than $30 \%$ assess the services related to software and IT consultancy and information as very innovative and $20.9 \%$ of them such a score assign to telecommunication services. The importance of ICT services for enterprises from the food processing sector is decided, inter alia, by their usefulness in the process of formation of their market position. An affect thereof is impact on competitiveness. Also from this viewpoint ICT cervices are assessed positively. 71.1 and $70.1 \%$ of enterprises declare their high, positive impact on raising competitiveness in case of information-related services as well as those related to software and IT consultancy, while $65.2 \%$ assess so telecommunication services.

When analysing the correlations between the responses to particular research questions and the variables characterising the enterprises surveyed, one may see - in accordance with expectations - generally positive correlations between them. The bigger are enterprises, the wider scope of their scope of activity and the higher share of foreign capital, the more positive are scores assigned to ICT services. There is only appearing the question whether the perceived tendencies are statistically significant. The application of the nonparametric Kruskal-Wallis and Mann-Whitney U tests (Table 3 ) shows that from among all 54 correlations analysed (6 research questions times 3 independent variables times 3 types of ICT services) the statistically significant correlation occurs in 24 cases. The level of significance $p$ of the test of variables independence did not exceed in these cases the critical value $p=0.05$, what means that there are no grounds for rejection of the hypothesis of correlation between variables.

Most often (14 cases) statistically significant correlations occurred in case of information-related services. They concerned all the questions in correlation with the enterprise size and their capital structure and, additionally, also correlations between assessments of innovativeness and the price and quality ratio and the businesses' range of operations. In relation to the services related to software and IT consultancy, such correlations appeared 8 times, of which five times for the variable describing the enterprise size (lack of correlations took place only in case of assessment of the price and quality ratio) and three times for the 'range of operations' variable (assessment of the degree of use of services, the price and quality ratio, and innovativeness). In case of telecommunication services, the statistically significant correlations occurred twice - this concerns the relationship between assessment of services innovativeness and the range of operations as well as assessment of the impact on competitiveness with capital structure.

However, the power of identified correlations is relatively weak. In eight cases, the calculated Cramer's $\mathrm{V}$ coefficient reaches value below 0.2 , in fifteen, it oscillates within $0.2-0.3$, and only in one case (cor- 
Proceedings of the 2018 International Scientific Conference 'Economic Sciences for Agribusiness and Rural Economy' No 2, Warsaw, 7-8 June 2018, pp. 51-58

Table 2. Use and assessment of ICT services at the enterprises surveyed

\begin{tabular}{|c|c|c|c|}
\hline Specification & $\begin{array}{l}\text { Telecommunication } \\
\text { services } \\
(\%)\end{array}$ & $\begin{array}{c}\text { Services related to software } \\
\text { and IT consultancy } \\
(\%)\end{array}$ & $\begin{array}{c}\text { Information-related } \\
\text { services } \\
(\%)\end{array}$ \\
\hline Use of ICT services & 100.0 & 74.6 & 59.2 \\
\hline \multicolumn{4}{|c|}{ Outlays dynamics } \\
\hline Outlays clearly decreased & $3.0 \%$ & 0.7 & 0.8 \\
\hline Outlays slightly decreased & 9.0 & 2.0 & 3.4 \\
\hline Outlays remained at the same level & 56.2 & 52.0 & 48.7 \\
\hline Outlays slightly increased & 25.9 & 35.3 & 36.1 \\
\hline Outlays clearly increased & 6.0 & 10.0 & 10.9 \\
\hline \multicolumn{4}{|c|}{ Assessment of quality } \\
\hline Low quality & 1.5 & 1.3 & 0.8 \\
\hline Average quality & 25.9 & 13.3 & 11.8 \\
\hline High quality & 50.7 & 54.0 & 57.1 \\
\hline Very high quality & 21.9 & 31.3 & 30.3 \\
\hline \multicolumn{4}{|c|}{ Price and quality ratio } \\
\hline Are worth much less & 1.0 & 0.0 & 0.8 \\
\hline Are worth slightly less & 14.9 & 10.0 & 10.9 \\
\hline Price is adequate & 72.1 & 69.3 & 68.1 \\
\hline Are worth lightly more & 8.0 & 15.3 & 16.0 \\
\hline Are worth much more & 4.0 & 5.3 & 4.2 \\
\hline \multicolumn{4}{|c|}{ Innovativeness } \\
\hline Not innovative at all/non-modern & 1.0 & 0.7 & 1.7 \\
\hline Rather not very innovative/not very modern & 9.0 & 4.0 & 5.0 \\
\hline I do not know/difficult to say & 11.9 & 8.7 & 10.1 \\
\hline Rather innovative/modern & 57.2 & 56.0 & 52.1 \\
\hline Very innovative/modern & 20.9 & 30.7 & 31.1 \\
\hline \multicolumn{4}{|c|}{ Assessment of the impact on enterprise's competitiveness } \\
\hline Difficult to say & 5.0 & 8.5 & 11.9 \\
\hline To a very low degree & 5.0 & 7.0 & 4.0 \\
\hline Rather to a low degree & 24.9 & 14.4 & 12.9 \\
\hline Rather to a high degree & 41.3 & 36.8 & 36.3 \\
\hline To a very high degree & 23.9 & 33.3 & 34.8 \\
\hline
\end{tabular}

Source: author's own research, 2014/2015. 
Proceedings of the 2018 International Scientific Conference 'Economic Sciences for Agribusiness and Rural Economy' No 2, Warsaw, 7-8 June 2018, pp. 51-58

Table 3. Analysis of correlations between the use and assessment of ICT services and the features of the businesses surveyed with the use of Kruskal-Wallis (for the enterprise size and range of operations) and Mann-Whitney $\mathrm{U}$ tests (for capital structure)

\begin{tabular}{|c|c|c|c|c|c|c|c|c|c|}
\hline \multirow{3}{*}{$\begin{array}{l}\text { Dependent } \\
\text { variable }\end{array}$} & \multicolumn{9}{|c|}{ Grouping variable } \\
\hline & \multicolumn{3}{|c|}{ enterprise size } & \multicolumn{3}{|c|}{ range of operations } & \multicolumn{3}{|c|}{ capital structure } \\
\hline & $\chi^{2}$ & sign. & $\begin{array}{c}\text { Cramer's } \\
\text { V }\end{array}$ & $\chi^{2}$ & sign. & $\begin{array}{c}\text { Cramer's } \\
\text { V }\end{array}$ & $\mathrm{Z}$ & sign. & $\begin{array}{c}\text { Cramer's } \\
\text { V }\end{array}$ \\
\hline \multicolumn{10}{|c|}{ Telecommunication services } \\
\hline Use & 0.000 & 1.000 & - & 0.000 & 1.000 & - & 0.000 & 1.000 & - \\
\hline $\begin{array}{l}\text { Outlays } \\
\text { dynamics }\end{array}$ & 1.395 & 0.498 & 0.190 & 6.318 & 0.097 & 0.187 & -0.491 & 0.623 & 0.168 \\
\hline Quality & 1.298 & 0.523 & 0.125 & 6.384 & 0.094 & 0.171 & -0.294 & 0.769 & 0.057 \\
\hline $\begin{array}{l}\text { Price and quality } \\
\text { ratio }\end{array}$ & 1.188 & 0.552 & 0.081 & 3.867 & 0.276 & 0.198 & -0.968 & 0.333 & 0.090 \\
\hline Innovativeness & 1.797 & 0.407 & 0.149 & 8.998 & 0.029 & 0.163 & -0.009 & 0.993 & 0.093 \\
\hline $\begin{array}{l}\text { Impact on } \\
\text { competitiveness }\end{array}$ & 3.188 & 0.203 & 0.191 & 5.115 & 0.164 & 0.149 & -2.014 & 0.044 & 0.170 \\
\hline \multicolumn{10}{|c|}{ Services related to software and IT consultancy } \\
\hline Use & 7.593 & 0.022 & 0.195 & 8.664 & 0.034 & 0.208 & -0.810 & 0.418 & 0.057 \\
\hline $\begin{array}{l}\text { Outlays } \\
\text { dynamics }\end{array}$ & 10.412 & 0.005 & 0.215 & 6.099 & 0.107 & 0.188 & -0.633 & 0.527 & 0.219 \\
\hline Quality & 16.752 & 0.000 & 0.237 & 6.579 & 0.087 & 0.178 & -1.063 & 0.288 & 0.107 \\
\hline $\begin{array}{l}\text { Price and quality } \\
\text { ratio }\end{array}$ & 4.833 & 0.089 & 0.161 & 8.072 & 0.045 & 0.180 & -0.392 & 0.695 & 0.077 \\
\hline Innovativeness & 17.448 & 0.000 & 0.270 & 11.796 & 0.008 & 0.179 & -1.161 & 0.246 & 0.154 \\
\hline $\begin{array}{l}\text { Impact on } \\
\text { competitiveness }\end{array}$ & 10.028 & 0.007 & 0.220 & 7.002 & 0.072 & 0.152 & -0.761 & 0.447 & 0.119 \\
\hline \multicolumn{10}{|c|}{ Information-related services } \\
\hline Use & 9.373 & 0.009 & 0.216 & 6.451 & 0.092 & 0.180 & -2.685 & 0.007 & 0.190 \\
\hline $\begin{array}{l}\text { Outlays } \\
\text { dynamics }\end{array}$ & 11.097 & 0.004 & 0.221 & 6.190 & 0.103 & 0.205 & -2.858 & 0.004 & 0.332 \\
\hline Quality & 11.278 & 0.004 & 0.205 & 5.351 & 0.148 & 0.170 & -2.334 & 0.020 & 0.208 \\
\hline $\begin{array}{l}\text { Price and quality } \\
\text { ratio }\end{array}$ & 8.042 & 0.018 & 0.198 & 8.302 & 0.040 & 0.233 & -2.710 & 0.007 & 0.236 \\
\hline Innovativeness & 15.739 & 0.000 & 0.239 & 10.518 & 0.015 & 0.171 & -2.748 & 0.006 & 0.235 \\
\hline $\begin{array}{l}\text { Impact on } \\
\text { competitiveness }\end{array}$ & 13.650 & 0.001 & 0.240 & 4.325 & 0.228 & 0.153 & -2.755 & 0.006 & 0.203 \\
\hline
\end{tabular}

Source: author's own research, 2014/2015. 
relation between the dynamics of outlays on information-related services and enterprise's capital origin) exceeds 0.3 reaching the value of 0.332 .

\section{CONCLUSIONS}

The evolution of the contemporary world related to the development of information societies sets forth the demand to apply more and more advanced technologies. The presented research findings show that this trend is also noticed in the food processing sector. This is confirmed by the indices showing the significant importance of modern ICT services for functioning of enterprises operating in this sector. The very ICT services also deserve positive assessments - they are perceived as modern, of high quality and adequate value related to their price as well as useful from the point of view of their impact on competitiveness.

A significant phenomenon is also the relatively high differentiation of assessments depending on the features characterising the entities in question. Higher scores are primarily specific for bigger entities, with a wider scope of activity as well as those using the support of foreign capital. Based on this, we may conclude that the potential area for improving ICT services in Poland is improvement of the relationships between service providers and customers from the SME sector, connected, i.a. with creation of the offer of services better adjust to their needs and taking into account specific conditions of activity.

This category of enterprises - undoubtedly dominating in the entire economy - is characterised by a limited use of ICT services (in comparison to large business entities) on the one hand, and the greatest flexibility regarding their implementation on the other.

The role of enterprises with foreign capital also deserves our attention. With greater capital at their disposal and benefits associated with using the experience transfer red from other countries, they tend to set trends with regard to the practical application of modern technologies.

\section{Acknowledgements}

The research, being the grounds for this study, was carried out within the framework of the implemen- tation of the project financed by the National Science Centre (NCN) 2013/09/B/HS4/02733, entitled 'Innowacyjność usług biznesowych w podnoszeniu konkurencyjności przedsiębiorstw - ujęcie modelowe' [Innovativeness of Business Services in Raising Enterprises' Competitiveness. The Model Approach].

\section{REFERENCES}

1. Bell, D. (1973). The coming of post-industrial society: A venture in social forecasting, Basic Books, New York.

2. Castells, M. (1996). The information age: economy, society and culture. The rise of network society, Vol. 1, Blackwell Publishers, Oxford.

3. Castells, M. (1997). The information age: economy, society and culture. The rise of network society. Vol. 2, Blackwell Publishers, Oxford.

4. Castells, M. (1998). The information age: economy, society and culture. The rise of network society. Vol. 3, Blackwell Publishers, Oxford.

5. Dąbrowska, A., Janoś-Kresło, M., Wódkowski, A. (2009). E-usługi a społeczeństwo informacyjne [E-services and the information society]. Difin, Warszawa.

6. Drucker, P.F. (1968). The age of discontinuity: guidelines to our changing society. Harper and Row, New York.

7. Drucker, P.F. (1993). Post-capitalist society. Harper Business, New York.

8. Goban-Klas, T., Sienkiewicz, P. (1999). Społeczeństwo informacyjne: Szanse, zagrożenia, wyzwania [Information society: Opportunities, threats, and challenges]. Wydawnictwo Fundacji Postępu Telekomunikacji, Kraków.

9. GUS (2008). Społeczeństwo informacyjne w Polsce. Wyniki badań statystycznych z lat 2004-2007 [Information society in Poland. Findings of statistical surveys in the years 2004-2007]. Informacje i Opracowania Statystyczne. Dział Wydawnictw Statystycznych, Warszawa.

10. GUS (2010). Społeczeństwo informacyjne w Polsce. Wyniki badań statystycznych z lat 2006-2010 [Information society in Poland. Findings of statistical surveys in the years 2006-2010]. Informacje i Opracowania Statystyczne. Dział Wydawnictw Statystycznych, Warszawa.

11. GUS (2017). Społeczeństwo informacyjne w Polsce. Wyniki badań statystycznych z lat 2013-2017 [Information society in Poland. Findings of statistical surveys in 
the years 2013-2017]. Informacje i Opracowania Statystyczne. Dział Wydawnictw Statystycznych, Warszawa.

12. Kisielnicki, J. (ed.) (2008). Informatyka dla przyszłości (Information technology for the future). Wydział Zarządzania Uniwersytetu Warszawskiego, Warszawa.

13. Kluszczyński, R. (2001). Społeczeństwo informacyjne. Cyberkultura. Sztuka multimediów [Information society. Cyberculture. Art of multimedia]. Rabid, Kraków.

14. Kuczewska, L., Nowacki, R. (2016), Innowacyjność usług biznesowych w podnoszeniu konkurencyjności przedsiębiorstw [Innovativeness of business services in raising enterprises' competitiveness]. PWE, Warszawa.

15. Machlup, F. (1962), The production and distribution of knowledge in the United States. Princeton University Press, Princeton.
16. MSWiA (2008). Strategia rozwoju społeczeństwa informacyjnego w Polsce do roku 2013 [Strategy of development of the information society in Poland up to the year 2013]. Warszawa.

17. Nowacki, R. (2017). Digitalizacja reklamy - stan, uwarunkowania, perspektywy [Digitalisation of Advertising. The state, conditions, perspectives]. Handel Wewnętrzny, 63 (6), pp. 244-256.

18. OECD (2004). Information and communications technologies. OECD Information Technology Outlook, Paris.

19. Olszewski, J. (2013). Ewolucja gospodarki w kierunku społeczeństwa informacyjnego [Evolution of the economy towards the information society]. Studia Oeconomica Posnaniensia, 1 (6), pp. 69-87.

20. Toffler, A. (1980). The third wave. Bantam Books, New York. 